\title{
The Problems and Countermeasures of Music Education in Current Colleges and Universities
}

\author{
Rui Gao \\ School of Teacher Education, Qujing Normal University, Qujing, Yunnan, China
}

Keywords: Music education, Problem, Reform, Countermeasure

\begin{abstract}
In this paper, the music education in colleges and universities as the research content, aimed at the study of music education in colleges and universities, music education and teaching reform and development of new ideas. And tries to solve the shortcomings of the current teaching model of music education in colleges and universities, find out the way to solve the problem, and find the strategies to improve the teaching of music education in colleges and universities. So that the development of music education in colleges and universities to the modernization and scientific direction of the development of far-reaching theoretical and practical significance.
\end{abstract}

\section{The Development of Music Education in Normal Colleges}

Since the reform and opening up, a large number of advanced foreign music education ideas and methods were introduced to China. Drawing lessons from foreign advanced music education ideas and methods to promote the reform and development of China's music education are difficult and complex system engineering. To revitalize and promote the development of music education in China, we must truly see our current and foreign advanced music education ideas and theoretical gap always adhere to a comprehensive, systematic, objective and scientific attitude, learning, master its theoretical system and practical experience [1]. In terms of the whole country, although many colleges and universities have begun to study the music teaching reform and initially in the curriculum, teaching resources, and so do a lot of work and show the prototype, but the real sense of service in the basic music education development and requirements of the teaching model also Need to continue to improve and perfect. According to the literature search, the teaching reform of music education in normal colleges needs deep systematic research. In the current situation of music education in normal colleges, there are mainly drawbacks in the following aspects: First, the training objectives are not clear, leading to teaching content, teaching methods of specialized tendencies: Second, the teaching content is more single, so that students can't master A qualified music teacher should have the basic skills; third, heavy professional learning, light education practice.

In the 21st century, music education in colleges and universities appeared in the following obvious new trends: on the one hand, Pop music began to enter the university music education. Secondly, the state promulgated the "music curriculum standards", teaching courses have a unified standard. Thirdly, Social forces are growing. The number of undergraduate colleges offering music education is increased, and the number of students enrolled in music education is increased. Fourth, the curriculum and teaching objectives of music education in colleges and universities have clear guiding rules. The teaching practice of college music education specialty, the training plan, the curriculum standard and the performance standard should be carried out in accordance with the national regulations and teaching standards, and explore the road of innovation and development which conforms to the local characteristics.

\section{The Importance of Music Education}

Music art education is an indispensable part of school education. It is irreplaceable to cultivate the art of music and art, to improve the aesthetic taste of the people, to make a noble aesthetic ideal, music art education has an irreplaceable role[2]. It is a melodious melody, changing the rhythm, colorful sound, mellow bright harmony, clever and delicate structure and unique way to shake people's minds, 
the complex inner world have a direct role in the induction. The music in the "pentameter" and the development of human temperament closely linked. The ancients still know that the art of music for the cultivation of the ideological and sentiment of the special role, we should realize that music for the cultivation of people, shaping the importance of people.

Music art education is the breakthrough to realize the change of "examination- oriented education" to "quality-oriented education".From "examination-oriented education" to "quality education", is a major direction of education reform. The essence of reform is to take the education in the competition test as the main goal of education, in accordance with the law of education, students in Germany, wisdom, body, beauty, labor and other aspects of comprehensive development as the main goal, and continue Innovative education, so that education really for all students, for students to learn life, knowledge, fitness, aesthetic, labor, life lay a solid foundation. Therefore, the strengthening of music education is one of the important measures to achieve this change. Higher education is a high level of quality education. In the university to strengthen the music art education, can promote the development of students 'image thinking ability, through the image of thinking and logical thinking of the organic combination to improve students' creative thinking ability.

Music art education is an important link in advancing the construction of socialist spiritual civilization. Music art education belongs to the superstructure, belongs to the category of spiritual civilization. Ancient China to promote "rituals to rule the country", the so-called "ceremony", that is, behavioral norms; "music" is the spirit of cultivation. The improvement of the realm of human spirit can't rely on subjective self-cultivation, such as face-to-face, self-examination, etc., must also be achieved through the influence of education and the outside world. The combination of behavioral norms and artistic cultivation is the tradition of Chinese education. In the implementation of reform and opening up and accelerate the socialist market economic construction of the new situation, the art of cultivation is indispensable. Through the positive and healthy music art education, to promote the socialist "true", "good" and "beauty".

\section{The Outstanding Problems of Music Education in Universities}

Discipline setting is not scientific, teaching subjects are more single. The contents of the curriculum of music education in our country are basically the same, including basic knowledge of music, musical instrument operation, music theory and so on, and some elective courses. These courses are set up in accordance with the requirements of the Ministry of Education "School Art Education Regulations" and "2001-2010 National School Art Education Development Plan". The characteristics of the discipline of music professionals require students in addition to master the basic knowledge of music theory, to focus on learning professional knowledge and skills, emphasizing the individuality of music education. At present, the subject setting of music education in our country can’t fully meet the requirements of individuality of music education.

There is no well-matched education model for the needs of talent training. At present, there are many drawbacks in the teaching mode of higher music education in our country, which have a negative impact on the cultivation of music talents. Specific performance in the following areas: First, the teaching objectives are too single, the current status of music education in colleges and universities are one-to-one relationship, there will be a one-to-many or one-to-one situation. Second, teaching can't be achieved with students as the main body. The important idea of contemporary teaching model is based on students as the main body.

Music teaching methods are too single. At present, the music education in colleges and universities does not take into account the individual differences of students, the flexibility and necessity of music practice. Some colleges and universities still use the traditional spoon-feeding and classroom teaching methods, which seriously affect the students' autonomous learning and teaching effect is not optimistic.

The music education innovation is weak, and the curriculum setting is single and rigid. Music education in colleges and universities was originally a full of vitality of the course, but because the teaching content is too single, the curriculum design is too rigid, the music classroom to become a stagnant pool, lifeless, let alone music education innovation. Most of the music education in colleges 
and universities evolved from foreign music education, too much from the foreign music education model and neglected the traditional music education tradition, in the curriculum is also a copy of the content of foreign courses, did not form their own characteristics.

In addition, the teachers' professional accomplishment is not enough, and the course of music education is also rigid. Music teaching is a kind of aesthetic education has evolved into a task to complete the teaching, so that the beauty of music gone, students learn it is also tasteless. In order to effectively improve the quality of teaching music education, we must first give enough music education Attention, because only the college music education to a higher position, in order to glow out of the university music education practitioners sense of responsibility and mission, will let them sacrifice for the music education life is also regrettable. To give college music education enough attention to the degree, is to run the basis of quality education. Quality education is a considerable part of the aesthetic education, and music education is to let students feel the beauty of music, is a part of aesthetic education. In the concept of quality education was shouted for so many years, the substantive quality of education has yet to be developed. Colleges and universities not only to bear the training for the needs of social construction of practical talents, but also shoulder the overall quality of personnel to enhance the development of all-round development of high-quality talent. Music literacy to become the necessary quality of high-quality talent, which college music education in accordance with the requirements of quality education, and constantly improve the quality and level of education and teaching

Assessment methods are not flexible enough, and the assessment results can't fully reflect the level of student ability. As a student of learning music, must have a certain ability to express, to music knowledge and theory with the performance fully reflected. At present, most of the domestic college music education majors follow the other professional assessment methods, the students' theoretical knowledge ability as the main standard of professional assessment, the actual operation of the assessment is also tasted, the examination results are difficult to truly reflect the students on music Knowledge of the ability to master.

\section{Reasons for the Quality of Music Education in Chinese Universities}

The music education in colleges lacks knowledge. Marx said: "The idea of nothing is nothing more than something that moves into the human mind and transforms it in the human mind." The concept not only reflects the objective material world, but in the consciousness to create the material object form, become the practice of ideological guidance. The concept of renewal is the prerequisite for deepening understanding. At present, some institutions leaders and cadres to carry out music education, there are some errors, one-sided understanding, the fundamental reason is not fully aware of music education in college education play an important role, so that they do not want to focus, Material resources into the development of music education.

Attention to form but light effect. Many institutions in the construction of cultural activities, a large part of the tendency to grasp the construction, while ignoring the real content. This is one of the reasons, first, in the process of building music education as a task to complete the task and the annual work to complete the index, to engage in several activities, add facilities can be. So pay attention to the various facilities blindly pursue the external form, while ignoring the actual effect. Second, the starting point for the development of music education is not correct, the music education and other activities are exactly the same as the student's amateur cultural activities, heavy form rather than the inherent spirit of the creation of culture, ignoring its deep sense of education for students[3]. The number of students located in the number of students to participate in music education is always the number of students to attend the number of hard targets, in the form of large-scale pomp, scenes lively, for the purpose of diversity, they often overlook the spirit of music education In essence, not from the shaping of student values and personal growth reality, resulting in many institutions in music education construction in the form.

Institutional construction is lagging behind. The normal development of music education requires a certain system for protection, mainly including the organizational system, management system and work system, but the reality is not optimistic. At present, many teachers colleges in 
carrying out music education system construction mostly in the surface phenomenon, and some are not included in the formal channels. Music education is the need to carry out a scientific, normative system as a strong guarantee. In the organizational system, some institutions in principle is arranged for the specialized staff is mainly responsible, but the responsibility is not clear, positioning is unknown, often one person is full of office. In the management system, many institutions often only do a look, put a shelf, not in summing up the unit to carry out the experience of music education on the basis of a set of reflect the characteristics of the unit, reflecting the requirements of the masses of the work system, there is no practical effect. In the work system, more institutions that music education is not the center of the work of the institution, it is important to say, do it again, busy up do not, inevitably, regardless of, and difficult to manage the phenomenon[4]. This phenomenon continues again and again, will inevitably affect the smooth development of music education in colleges and universities, affecting its effectiveness to play.

Hardware infrastructure is weak. For a long time, to carry out the main investment of music education, the various institutions into the music education, the funds become more and more inadequate. Many institutions of cultural equipment is limited to "a few machines a few tables", "a few boxes of a few boxes", style equipment is not on the grade. In recent years, although for the development of music education has invested a lot of money, but from the actual needs or there is a big gap. Most of the institutions of education funding can only meet the basic teaching needs of $60 \%$, per capita funding is far lower than the developed countries. Due to lack of capital investment, resulting in many facilities can't be updated and improved in time, activities can't be equipped with equipment, regular activities can’t be normal, which is currently many homes.

\section{Reform Measures of Music Education in Colleges and Universities}

The reform of music education in colleges and universities should be based on the previous experiences and lessons, combined with the new trend of international diversification, and finally reached the comprehensive improvement of music education and teaching.

Adhere to the development of quality education.Quality education is the future development direction of colleges and universities in China, and should also be the direction of music education[5]. The future of music education in the implementation of quality education requirementsis to adhere to the music education as a student aesthetic ability, emotional quality and intelligent quality of the important way in the process of discipline education to fully stimulate the enthusiasm and creativity of students to develop students to analyze and use The ability of music theory. The development of students as the purpose of physical and mental, and students of all kinds of quality factors have been fully developed.

Locate the properties of the discipline. The purpose of music education is to cultivate the students' comprehensive quality, especially the humanistic quality. Therefore, music education belongs to the subject of humanities education. It should set up the teaching content and teaching method according to the teaching law of humanities subject, perfect the discipline system construction as soon as possible, Focusing on the promotion of the Chinese nation's outstanding culture and the diversity of world culture in the direction of education students not only to learn and promote China's outstanding national music culture, enhance national consciousness and patriotism, but also learn and understand the rest of the world and national Music culture; not only to learn from the European Renaissance since the various schools of professional music creative achievements, but also to learn the world's music culture area of outstanding national music, so that students establish equal multi-cultural values, sharing all the outstanding achievements of human civilization.

Combined with science education, speed up the pace of reform. The development of music education in colleges and universities is the development of curriculum, teaching materials and disciplines. Therefore, it is necessary to organize experts and scholars to study and prepare scientific and reasonable system teaching materials suitable for ordinary college or non-professional students' music teaching. Keep up with the development of the times, the contemporary college students keen on the network, Walkman, etc., set up a new batch of music courses, and gradually grasp the discipline construction, and ultimately the formation of science, reasonable, standardized, theory 
combined with the actual teaching system[6]. Strengthen the comprehensive management of music teaching and the supervision of the teaching process, the practical implementation of the modern teaching concept, so that the college music teaching can really play its aesthetic, moral and entertainment and other multiple functions, thereby improving the comprehensive ability of college students.

Music teaching must also strengthen practice. All the truth of the test standards only practice, music is no exception, no matter which subject of learning, their ultimate foothold will be practice. Therefore, music teaching must be the theory of practice, practice teaching and practice combination, in the class at the same time, for students to provide more practice opportunities.

Have a scientific assessment method. Perfect evaluation system as an important aspect of the reform of teaching mode of music education in colleges and universities, it is of great significance to establish the concept of "education-oriented", to pursue and inspire "lifelong learning".

\section{References}

[1] Q.W. Lu, The enlightenment of foreign music education thought on Chinese music education, Journal of Shandong University of Technology, 2005 vol.2, pp. 103-106.

[2] T. Lin, The theoretical significance and main practical approaches of music activities in colleges and universities, East China Institute of Technology, 2006, vol.4, pp.217-219.

[3] A.G. Wang, From practice to decision-making, Huacheng Publishing House, 2004, vol.6, pp.21-24.

[4] S.Y. Yao, On music and music education, Beijing: Higher Education Press, 2004,vol.2, pp.33-35.

[5] X.F. Li, Music education in colleges and universities in the existing problems and countermeasures, Ethnic Education Research, 2006, vol.5, pp. 15-18.

[6] D.C. Dai, Music education outlook, East China Normal University Press, 2001, vol.13, pp. 77-79 